\title{
CORRESPONDENCE
}

\section{Biotechnology and scientific collaboration}

SIR, - In a recent issue of Nature (10 January, page 125) I was pleased to note in Robert Walgate's article the inclusion in the proposed EEC programme on biotechnology of "development of reactors for reactions at a hydro-organic interface", since our

Biotechnology Unit has been responsible for several $\mathrm{PhD}$ theses and published papers related to this topic. The unit, set up several years ago, did effectively organise collaboration between biochemists, chemical engineers and microbiologists in this and other fields.

It was therefore surprising to read on the following page that "Lilly's group is unique in the UK in combining chemical engineers and biologists". While this group has indeed been pre-eminent in developing recognition of enzyme technology in this country, Dr Walgate could have ascertained that it was not unique, by reading the 1976 Report to the SRC and Institution of Chemical Engineers by A.N. Emery which cites at least four UK universities where such collaboration occurs.

A point of more concern is evidence of conceptual isolation of food science from biotechnology. Both involve application of the same basic disciplines of biochemistry, microbiology and chemical engineering and are similarly concerned with the provision, processing and utilisation of natural products. Both involve enzyme technology. This isolation is surely based more on territorial tribalism among applied scientists and their professional organisations than on a rational approach to the subject matter.

Now that the universities have entered lean years, where the relationships between the financial bones and the semantic skins are more carefully scrutinised, it is to be hoped that the various bodies concerned with biotechnological planning will not take too narrow a view of existing and potential assets. Yours faithfully,

University of Strathclyde, Glasgow, UK

\section{J.A. BLAIN}

\section{FAST's biotechnology programme}

SIR, - Your issue of 10 January focusing on biotechnology was timely and relevant, in emphasising that "the middle-term problem rests with governments", and that "this is precisely the moment when patterns of research will be formed which will ultimately shape lives". The Commission's "FAST" programme (Forecasting and Assessment in the field of Science and Technology) was set up by decision of the Council of Ministers to highlight prospects, problems and potential conflicts likely to affect longterm development of the Community and define alternative courses of Community research and development action.

Biotechnology - or more broadly, a "biosociety" scenario - has been selected as one of our three central themes, and within this we shall be sponsoring a number of research studies covering such related long-term issues as Community research and development strategy, manpower and training implications, social acceptability, Third World implications, and environmental engineering; further details are available on request.

I should point out that the FAST programme is distinct from the biomolecular engineering programme described in your issue of 10 January, though naturally we have the benefit of collaboration with our Commission colleagues, both from this programme and elsewhere in the Commission. Yours faithfully,

MARK F. CANTLEY Commission of the European Communities, Brussels

\section{Shortage of science teachers}

SiR, - It is reported in Nature (17 January, page 233) that there are serious shortages of teachers of mathematics and natural sciences, particularly physics, and it is revealed that of our secondary school teachers of physics only $43 \%$ are qualified to teach physics. Your report contains the wise and timely warning, "without well-qualified science teachers, there is little hope for the future of science and engineering in Britain". I wish to present the case that the situation is in fact even more serious than the figures suggest.

Firstly, I question the suitability of the education of many (or probably, most) of those who are "qualified to teach physics". University graduates generally have acquired an imperfect knowledge of advanced work in a specialist subject. To teach physics in school one requires a very thorough understanding of the elementary principles of the science, and also considerable knowledge of the relationship between physics and other subjects.

Secondly, there is a tacit assumption in all educational thinking that teachers and pupils can easily obtain trustworthy information about any subject by reading textbooks. It is now 20 years since the writer first drew attention to the incredible accuracy of very many physics textbooks, particularly at sixth form level. During the past 20 years a very few publishers have attempted to improve their own books, but the general standard has continued to decline.

As it is obvious that we cannot quickly remedy the shortage of suitably trained teachers, surely it is obvious that we must help the teachers we have by ensuring that they have accurate sources of information. Yours faithfully,

J.W. WARREN Brunel University, Uxbridge, Middlesex, UK

\section{Brazil's fuel technology}

SIR, - I was very interested in the article on alternative fuel technology in Brazil (6 December, page 550) which you published recently. Unfortunately, in the discussion of ethanol production, the author did not answer the one question which seems to me the most important in this whole project. Where does the fuel come from to distil the ethanol? By fermentation, ethanol can only be produced in dilute aqueous solution, and the amount of energy needed to fractionally distil this may be greater than the energy obtained from burning the ethanol.
It seems to me that this need for an energy input to fractionate the ethanol may be a fatal weakness in the whole ethanol project. It is avoided by the use of methanol, which is not produced in dilute solution, and may be made, for example, from wood via charcoal.

$$
\begin{gathered}
\text { Yours faithfully, } \\
\text { DAVID A.H. TAYLOR } \\
\text { University of Natal, Durban, Natal }
\end{gathered}
$$

\section{Nuclear power}

SIR, - There seems to have been a serious misprint in the penultimate paragraph of the article on Nuclear Power: the threat to personal freedom in the 20-27 December issue (page 774). The paragraph states that the pursuit of nuclear power could conceivably damage civil liberties less than would the pursuit of a high conservation/low energy strategy as outlined earlier this year by the International Institute for Environment and Development. Since the IIED strategy does not touch personal liberties and at most calls for mandatory targets to be set for the energy performance of products such as cars and new buildings, thus merely altering the range of consumer choice in one respect, the paragraph is clearly back to front. Energy conservation may have to be forced through by 'controls' on individuals only if we do 'too little, too late'; but no critic has yet accused the IIED scenario of that! And even controls of this kind are a long way from armed police and security vetting.

Yours faithfully,

GeRALD LEACH

International Institute for Environment \& Development, London, UK

\section{Job-swapping}

SIR, - In regard to your editorial on jobswapping (4 October, page 327), I had the good fortune to exchange jobs and houses with a librarian in Scotland for an academic year and would do it again eagerly.

It did, however, require a fairly substantial amount for travel expenses and salaries, which therefore were paid by our home institutions. I think your point about the necessity for a 3-5 year tenure is unnecessary and, on the contrary, for family reasons, I would suggest a 2-3 year exchange.

$$
\text { Yours faithfully, }
$$

California Institute of Technology, Pasadena, US

\section{New Jersey Turnpike}

SIR, - Robert Claiborne (20/27 December, page 776) says that my "attitude to facts is not beyond criticism", but his basis for this statement is manufactured out of context. I said that on a specific occasion the odors and visual obscuration ("like twilight or an eclipse of the sun") described in the book did not occur. The book implied (p102) that this alleged nuisance, caused by the large petrochemical complex near the New Jersey Turnpike, is not even occasionally abated. I lived near the complex for 21 years, and the statement in the book is incorrect. Yours faithfully, 